\title{
ANALISIS PERILAKU DISIPLIN DAN PROKRASTINASI AKADEMIK MAHASISWA (Studi pada Mahasiswa/I Prodi Perbankan Syariah FEBI IAI Darussalam Martapura)
}

\author{
Lola Malihah $^{1}$, Gusti Tasya Meilania ${ }^{2}$ \\ ${ }^{1}$ Program Studi Perbankan Syariah, Fakultas Ekonomi Dan Bisnis Islam \\ Institut Agama Islam Darussalam Martapura \\ ${ }^{2}$ Program Studi Statistika, Fakultas Mateamtika Dan Ilmu Pengetahuan Alam \\ Universitas Lambung Mangkurat \\ lolatasya@gmail.com
}

\begin{abstract}
In the management of human resources management, displin is a very important thing. Discipline can be the key to one's success both in career and academic. But the fact that discipline is often overlooked by most people, especially by students. Whereas discipline is very important in the world of education. This research was conducted on students of Sharia Banking Study Program FEBI IAI Darussalam Martapura from 2016 to 2019. Based on the results of the analysis, it is known that most of the students of The Sharia Banking Study Program FEBI IAI Darussalam fall into the category of discipline. Even so, there are still some students who fall into the undisciplined category. Therefore, further efforts must be made to optimize the discipline attitude of the student.
\end{abstract}

Keywords: Discipline, Academic Procrastination.

\begin{abstract}
ABSTRAK
Dalam pengelolan manajemen sumber daya manusia, displin merupakan hal yang sangat penting. Disiplin bisa menjadi kunci kesuksesan seseorang baik dalam karir maupun akademik. Namun faktanya disiplin sering kali terabaikan oleh sebagian besar orang terutama oleh mahasiswa/i. Padahal disiplin sangat penting dalam dunia pendidikan. Penelitian ini dilakukan terhadap mahasiswa/i Program Studi Perbankan Syariah FEBI IAI Darussalam Martapura dari angkatan 2016 sampai 2019. Berdasarkan hasil analisis yang dilakukan, diketahui bahwa sebagian besar mahasiswa/i Program Studi Perbankan Syariah FEBI IAI Darussalam masuk dalam kategori disiplin. Meskipun begitu, masih ada beberapa mahasiswa/i yang masuk kategori tidak disiplin. Sehingga harus dilakukan upaya lebih lanjut untuk mengoptimalkan sikap disiplin mahasiswa/i tersebut.
\end{abstract}

Kata Kunci : Disiplin, Prokrastinasi Akademik.

\section{PENDAHULUAN}

Disiplin adalah merupakan salah satu hal yang sangat penting, karena disiplin merupakan masalah yang sering sekali dihadapi dalam kehidupan sehari-hari, baik dilingkungan keluarga, lingkungan sekolah dan dilingkungan kerja. Disiplin merupakan sebuah sikap yang menunjukan kesediaan untuk mematuhi atau menepati aturan, tata tertib ketetntuan serta nilai-nilai yang berlaku. Disiplin mengandung asas ketaatan, yaitu kemauan dan kemampuan untuk bersikap dan bertindak secara konsisiten terhadap nilainilai yang telah ditentukan.

Dalam bidang manajemen sumber daya manusia, kedisiplinan adalah merupakan fungsi yang penting dan menjadi indikator apakah fungsi-fungsi MSDM lainnya secara menyeluruh telah dilaksanakan dengan baik. Kedisiplinan dalam sebuah organisasi menjadi cerminan bahwa fungsi-fungsi MSDM lainnya telah dilaksanakan sesuai dengan rencana, tetapi sebaliknya jika kedisiplinan anggota organisasi kurang baik, hal menunjukkan bahwa fungsi-fungsi MSDM pada organisasi tersebut juga kurang baik.

Dalam pengelolaan pendidikan, baik di tingkat dasar, menengah sampai pendidikan tinggi disiplin menjadi pencegah terjadinya hal-hal yang dapat menjadi pengganggu atau penghambat kelancaran proses belajar mengajar. Untuk itu dibuat dan diberlakukan berbagai macam peraturan dan tata tertib untuk menegakkan kedisipinan. Salah satu cara dengan dikeluarkannnya peraturan 


\section{Journal MISSY}

\section{(Management and Business Strategy)}

Vol. 2, Nomor. 1 Juni 2021

ISSN : 2775-3700

dilembaga pendidikan. Pertauran itu berupa tata tertib, sampai sanksi jika terjadi pelanggaran.

Dalam proses pendidikan sering kali terjadi hal-hal yang menyimpang dari peraturan yang atau tata tertib yang berlaku, misalnya kelalaian siswa atau mahasiswa. Kelalaian dalam hal waktu belajar atau kelalaian dalam pelaksanaan tugas diluar jam belajar. Misalnya menunda-nunda melaksanakan tugas yang diberikan atau bahkan tidak mengerjakan, yang akan berdampak pada banyak hal, termasuk keterlambatan masa selesai studi.

Program Studi Perbankan Syariah yang ada di Fakultas Ekonomi dan Bisnis Islam Institut Agam Islam Darussalam Martapura mulai beroperasi sejak tahun akademik 2016-2017, Program Studi ini awalnya tergabung dalam Fakultas Syariah ketika kampus masih berstatus sebagai Sekolah Tinggi Agama Islam (STAI) Darussalam Martpaura. Pada tahun 2017 didirikan Fakultas Ekonomi dan Bisnis Islam seiring dengan perubahan status dari Sekolah Tinggi (STAI) menjadi Institut Agama Islam Darussalam. Sejak saat itu Fakultas Ekonomi dan Bisnis Islam mempunyai dua Program Studi, yaitu Perbankan Syariah yang awalnya berada dibawah Fakultas Syariah dan Program Studi tambahan yaitu Ekonomi Syariah.

Mahasiswa angkatan 2016 yang pada tahun 2020 sudah berada di semester delapan dan seharusnya sudah menyelesaikan tugas akhir (skripsi) namun faktanya, dari 22 mahasiswa aktip, hanya ada 15 orang mahasiswa/i yang berhasil menyelesaikan tugas akhir tepat waktu dan masih ada 7 orang mahasiswa/i yang masih belum selesai tugas akhirnya. Hal ini membuat penulis tertarik untuk melakukan penelitian, penulis menduga kedisiplinan mempengaruhi aktivitas akademik mahasiswa Fakultas Ekonomi dan Bisnis Islam IAI Darussalam Martapura. Dalam penelitian ini peneliti juga melibatkan mahasiswa/i dari angkatan lainnya seperti angkatan 2017. 2018 dan juga 2019.

\section{METODE PENELITIAN}

Lokasipenelitian adalah di Kampus IAI Darussalam Martapura, dalam hal ini mahasiswa/i Program Studi Perbankan Syariah Fakultas Ekonomi dan Bisnis Islam, angkatan 2016. 2017, 2018, dan 2019 yang berjumlah sekitar 40 orang sebagai responden.

Penulis juga melakukan penelitian melalui observasi, evaluasi dan kepustakaan, yaitu dengan cara mengumpulkan data dari buku-buku, literatur, dokumen, jurnal ilmiah,dan berbagaisumber lain yang berhubungan dengan penelitian ini.

\section{HASIL DAN PEMBAHASAN Kriteria Disiplin dibidang akademik}

Kriteria Penilaian disiplin akademik dapat dilihat dari indikator :

1. Selalu hadir pada setiap jadwal perkuliahan, datang sebelum dosen masuk dan pulang setelah jam perkuliahan berakhir.

2. Selalu mengerjakan tugas yang diberikan oleh dosen dan diselesaikan tepat pada waktu yang telah ditentukan.

3. Mampu memanajemen waktu antara belajar dan kegiatan kemahaiswaan.

4. Lulus semua mata kuliah yang disajikan pada setiap semester.

5. Memperoleh nilai yang memuaskan.

6. Melaksanakan dan dapat meyelesaikan tugas akhir sesuai dengan waktu yang telah ditentukan.

7. Lulus kuliah tepat waktu.



Gambar 1. Responden Menurut Jenis Kelamin

Dalam penelitian ini, jumlah responden didominasi oleh mahasiswi 


\section{Journal MISSY}

\section{(Management and Business Strategy)}

Vol. 2, Nomor. 1 Juni 2021

ISSN : 2775-3700

(perempuan) dengan perbandingan persentase sebesar 63 persen dan mahasiswa (laki-laki) sebesar 37 persen.

1. Ketepatan waktu menghadiri perkuliahan

Tabel 1. Respon Terhadap Ketepatan Waktu

\begin{tabular}{|c|c|c|}
\hline $\begin{array}{c}\text { Sering } \\
\text { Terlambat }\end{array}$ & $\begin{array}{c}\text { Pernah } \\
\text { Terlambat }\end{array}$ & $\begin{array}{c}\text { Selalu Tepat } \\
\text { Waktu }\end{array}$ \\
\hline 5 & 26 & 9 \\
\hline $12,5 \%$ & $65 \%$ & $22,5 \%$ \\
\hline
\end{tabular}

Berdasarkan tabel di atas, dapat diketahui bahwa sebanyak 5 orang mahasiswa/i mengaku sering terlambat menghadiri perkuliahan, 26 orang mengaku pernah terlambat beberapa kali, serta 9 orang mengaku selalu datang atau menghadiri kuliah tepat waktu.

2. Tidak menghadiri perkuliahan tanpa keterangan (bolos)

Tabel 2. Respon Terhadap Kehadiran Kuliah

\begin{tabular}{|c|c|c|}
\hline $\begin{array}{c}\text { Sering } \\
\text { Bolos }\end{array}$ & $\begin{array}{c}\text { Pernah } \\
\text { Bolos }\end{array}$ & $\begin{array}{c}\text { Tidak Pernah } \\
\text { Bolos }\end{array}$ \\
\hline 4 & 9 & 27 \\
\hline $10 \%$ & $22,5 \%$ & $67,5 \%$ \\
\hline
\end{tabular}

Berdasarkan tabel di atas, dapat diketahui bahwa sebanyak 4 orang mahasiswa/i mengaku sering membolos, 9 orang mengaku pernah membolos beberapa kali, serta 27 orang mengaku selalu menghadiri perkuliahan.

3. Mematuhi aturan kampus

Tabel 3. Respon Terhadap Aturan Kampus

\begin{tabular}{|c|c|c|}
\hline $\begin{array}{c}\text { Sering } \\
\text { Melanggar }\end{array}$ & $\begin{array}{c}\text { Pernah } \\
\text { Melanggar }\end{array}$ & $\begin{array}{c}\text { Tidak Pernah } \\
\text { Melanggar }\end{array}$ \\
\hline 4 & 17 & 19 \\
\hline $10 \%$ & $42,5 \%$ & $47,5 \%$ \\
\hline
\end{tabular}

Berdasarkan tabel di atas, dapat diketahui bahwa sebanyak 4 orang mahasiswa/i mengaku sering melanggar peraturan kampus salah satunya tidak menggunakan pakaian sesuai dengan ketentuan kampus (memakai sepatu, baju longgar berkerah serta berbusana muslim bagi perempuan). , 17 orang mengaku pernah melanggar peraturan beberapa kali, serta 19 orang mengaku selalu mematuhi peraturan yang berlaku.
4. Kewajiban untuk mengerjakan tugas

Tabel 4. Respon Terhadap Pengerjaan Tugas

\begin{tabular}{|c|c|}
\hline Tidak Disiplin & Disiplin \\
\hline 19 & 21 \\
\hline $47,5 \%$ & $52,5 \%$ \\
\hline
\end{tabular}

Berdasarkan tabel di atas, dapat diketahui bahwa sebanyak 19 orang mahasiswa/i mengaku tidak disiplin dalam mengerjakan tugas oleh dosen seperti tidak mengerjakan maupun mengumpulkan tugas tepat waktu. Sedangkan 21 orang lainnya mengaku disiplin dalam mengerjakan tugas oleh dosen.

5. Ketertiban selama perkuliahan

Tabel 5. Respon Terhadap Ketertiban Kuliah

\begin{tabular}{|c|c|}
\hline Tidak Tertib & Tertib \\
\hline 1 & 39 \\
\hline $2,5 \%$ & $97,5 \%$ \\
\hline
\end{tabular}

Berdasarkan tabel di atas, dapat diketahui bahwa hanya 1 orang mahasiswa/i yang mengaku tidak tertibselama perkuliahan yaitu tertidur saat kuliah. Sedangkan 39 orang lainnya lainnya mengaku tertibselama perkuliahan berlangsung.

6. Prioritas akademik

\section{Tabel 6. Respon Terhadap Prioritas Akademik}

\begin{tabular}{|c|c|}
\hline Kegiatan Lain & Kegiatan Akademik \\
\hline 9 & 31 \\
\hline $22,5 \%$ & $77,5 \%$ \\
\hline
\end{tabular}

Berdasarkan tabel di atas, dapat diketahui bahwa 9 orang mahasiswa/i mengaku lebih mementingkan kegiatan lain salah satunya kegiatan organisasi mahasiswa. Sedangkan 31 orang lainnya mengaku lebih mementingkan tugas dan kegiatan akademik.

7. Respon terhadap tugas akademik

Tabel 7. Respon Terhadap Tugas Akademik

\begin{tabular}{|c|c|}
\hline $\begin{array}{c}\text { Menunda } \\
\text { Pengerjaan }\end{array}$ & $\begin{array}{c}\text { Langsung } \\
\text { Mengerjakan }\end{array}$ \\
\hline 11 & 29 \\
\hline $27,5 \%$ & $72,5 \%$ \\
\hline
\end{tabular}

Berdasarkan tabel di atas, dapat diketahui bahwa 11 orang mahasiswa/i mengaku lebih seringmenunda pengerjaan tugas dan mengerjakannya menjelang waktu 


\section{Journal MISSY}

\section{(Management and Business Strategy)}

Vol. 2, Nomor. 1 Juni 2021

ISSN : 2775-3700

pengumpulan. Sedangkan 29 orang lainnya mengaku langsung mengerjakan tugas yang diberikan meskipun waktu pengumpulan masih panjang.

8. Konsentrasi dalam pengerjaan tugas

Tabel 8. Respon Terhadap Konsentrasi Pengerjaan Tugas

\begin{tabular}{|c|c|}
\hline $\begin{array}{c}\text { Mudah Teralihkan } \\
\text { oleh Hal Lain }\end{array}$ & $\begin{array}{c}\text { Dapat } \\
\text { Berkonsentrasi } \\
\text { dengan Baik }\end{array}$ \\
\hline 18 & 22 \\
\hline $45 \%$ & $55 \%$ \\
\hline
\end{tabular}

Berdasarkan tabel di atas, dapat diketahui bahwa 18 orang mahasiswa/i mengaku mudah teralihkan konsentrasinya dengan hal-hal lain selama pengerjaan tugas. Sedangkan 22 orang lainnya mengaku dapat berkonsentrasi dengan baik selama mengerjakan tugas akademik.

9. Menyusun jadwal pengerjaan tugas akademik

Tabel 9. Respon Terhadap Penyusunan Jadwal

\begin{tabular}{|c|c|}
\hline $\begin{array}{c}\text { Tidak Menyusun } \\
\text { Jadwal }\end{array}$ & Menyusun Jadwal \\
\hline 13 & 27 \\
\hline $32,5 \%$ & $67,5 \%$ \\
\hline
\end{tabular}

Berdasarkan tabel di atas, dapat diketahui bahwa 13 orang mahasiswa/i mengaku tidak menyusun jadwal pengerjaan dan pengumpulan tugas kuliah sehingga tugas yang diberikan menumpuk. Sedangkan 27 orang lainnya mengaku menyusun jadwal pengerjaan dan pengumpulan tugas sehingga dapat memanajemen waktu dengan baik.

10. Dispensasi waktu pengerjaan tugas akademik

Tabel 10. Respon Terhadap Waktu Pengerjaan Tugas

\begin{tabular}{|c|c|}
\hline $\begin{array}{c}\text { Pernah Meminta } \\
\text { Dispensasi }\end{array}$ & $\begin{array}{c}\text { Tidak Pernah } \\
\text { Meminta Dispensasi }\end{array}$ \\
\hline 2 & 38 \\
\hline $5 \%$ & $95 \%$ \\
\hline Berdasarkan & tabel di atas \\
\hline
\end{tabular}

diketahui bahwa 2 orang mahasiswa/i mengaku pernah meminta dispensasi berupa penambahan waktu pengerjaan tugas akademik karena berbagai alasan seperti banyak tugas lain yang menumpuk serta ada kegiatan organisasi mahasiswa. Sedangkan 38 orang lainnya mengaku tidak pernah meminta dispensasi tersebut karena menganggap tugas yang diberikan tidak memberatkan sehingga dapat menyelesaikannya tepat waktu..

\section{KESIMPULAN}

Dari hasil analisis yang telah dilakukan, dapat disimpulkan bahwa sebagian besar mahasiswa/i Program Studi Perbankan Syariah FEBI IAI Darussalam masuk dalam kategori disiplin. Hal ini dikarenakan sebagian besar dari mereka mengaku bahwa tugas dan kegiatan akademik lebih penting daripada tugas dan kegiatan kemahasiswaan lainnya sehingga selalu hadir tepat waktu dan tertib dalam perkuliahan, mematuhi peraturan kampus serta mengerjakan tugas sesuai dengan arahan dosen dan mengumpulkannya tepat waktu.

Sebagian besar dari mereka juga mengaku menyusun jadwal pengerjaan dan pengumpulan tugas agar dapat mengerjakan tugas sesegera mungkin setelah tugas diberikan dan berusaha fokus selama pengerjaan tugas. Hal ini dilakukan sebagai upaya menghindari meminta dispensasi perpanjangan waktu pengerjaan tugas akibat ketidakmampuan mahasiswa/i dalam memanajemen waktu pengerjaan tugas akibat tugas yang menumpuk. Penulis berharap akan ada keberlanjutan dari penelitian ini, dengan tujuan untuk mengetahui apakah ada perubahan perilaku kesidiplinan akademik mahasiswa/i.

\section{DAFTAR PUSTAKA}

Damri, Engkizar, Fuady Anwar. Hubunhan Self-Effiency dan Prokrastinasi Akademik Mahasiswa Dalam Menyelesaikan Tugas Perkuliahan. Jurnal Edukasi UNP. Vol.3 No.2 Hal.74-95 2017.

Fauziah, Hanifah Hana, Faktor-faktor yan mempengaruhi Prokrastinasi Akademik pada Mahasiswa Fakultas Psikologi UIN Sunan Gunung Djati Bandung. Jurnal UINSGD Vol.2 No.1 Desember 2015. 


\section{Journal MISSY}

\section{(Management and Business Strategy)}

Vol. 2, Nomor. 1 Juni 2021

ISSN : 2775-3700

Handoko, T. Hani. 2016. Manajemen, Edisi Kedua. Yogyakarta: BPFE Yogyakarta.

Hasibuan, Malayu S.P. 2017. Manajemen Sumber Daya Manusia, Edisi Revisi. Bandung: Bumi Aksara.

Kristin, Firosalia dan Fransiska Faberta Kencana Sari. Pengaruh Kedisiplinan Belajar Terhadap Hasil Belajar Mahasiswa dalam Mata kuliah Konsep Dasar IPS. JPIS. Vol. 8 No.1, Juni, 2019.

Mangkunegara, Anwar Prabu. 2010. Evaluasi Kinerja SDM. PT Refika Aditama: Bandung

Muyana, Siti. Prokrastinasi Akademik Dikalangan Mahasiswa Program Studi Bimbingan dan Konseling. Jurnal Bimbingan dan Konseling Universitas Ahmad Dahlan Yogjakarta. Vol.8 No.1 (45-52) Mei 2018

Pamungkas, Adi Noor dan Hinadayati Mustafidah. Analisis Kedisiplinan Belajar Mahasiswa dan Kehadiran Mahasiswa terhadap nilai Mata kuliah Menggunakan Teori Kuantitatif Fuzzy. Jurnal Sainteks UMP. Vol. XIII No.1, Maret 2016. (71-82)

Pomalingo,Rivky. Silvya L Mandey, Yantje Uhing. Pengaruh Disiplin Kerja, Kompetensi, Dan Motivasi terhadap kinerja pegawai pada kantor Badan Penaggulangan Bencana Daerah Provinsi Sulawesi Utara. Jurnal Berkala Ilimiah Efisiensi, Vol.15 No.5 tahun 2015

Sugiyono, 2016. Metode Penelitian Kuantitatif, Kualitatif, dan $R \& D$. Bandung: Alfabeta.

Yadi, Inggar Januar, Victor G Simanjuntak, Ahmad Atiq. Tingkat Kedisiplinan Mahasiswa Dalam Proses Perkuliahan Jurusan Keolahragaan Prodi Penjaskesrek Pontianak 2014.
Jurnal Pendidikan dan pembelajaran Khatulisiwa. Vol. 4 No.2, 2015. 